Screening Enlightenment 
A VOLUME IN THE SERIES

\section{THE UNITED STATES IN THE WORLD}

edited by Mark Philip Bradley and Paul A. Kramer

A list of titles in this series is available at www.cornellpress.cornell.edu. 


\section{Screening Enlightenment}

Hollywood and the Cultural Reconstruction of Defeated Japan

Hiroshi Kitamura

Cornell University Press

Ithaca and London 
Copyright (C) 2010 by Cornell University

All rights reserved. Except for brief quotations in a review, this book, or parts thereof, must not be reproduced in any form without permission in writing from the publisher. For information, address Cornell University Press, Sage House, 512 East State Street, Ithaca, New York 14850.

First published 2010 by Cornell University Press

First printing, Cornell Paperbacks, 2017

\section{Library of Congress Cataloging-in-Publication Data}

Kitamura, Hiroshi, 1971-

Screening enlightenment : Hollywood and the cultural reconstruction of defeated Japan / Hiroshi Kitamura.

p. $\mathrm{cm}$.

Includes bibliographical references and index.

ISBN 978-0-8014-4599-6 (cloth : alk. paper)

ISBN 978-1-5017-1362-0 (pbk. : alk. paper)

1. Motion pictures, American-Japan-Influence. 2. Motion pictures-Social aspects - Japan-History. 3. Japan-History-Allied occupation, 1945-1952. 4. Japan-Civilization-American influences. 5. Japan-Civilization-1945- I. Title.

PN1993.5.J3K57 2010

791.43' $63585204-\mathrm{dc} 22 \quad 2009044415$

Cornell University Press strives to use environmentally responsible suppliers and materials to the fullest extent possible in the publishing of its books. Such materials include vegetable-based, low-VOC inks and acid-free papers that are recycled, totally chlorine-free, or partly composed of nonwood fibers. For further information, visit our website at www.cornellpress. cornell.edu. 
To my mother Mitsuyo Kitamura

and my late father Takao Kitamura, parents extraordinaire 
